\title{
Redesigning and Implementing Traditional Musical Instrument in Integrated Technology Classroom
}

\author{
https://doi.org/10.3991/ijet.v14i10.10197 \\ J. Julia ${ }^{(凶)}$, Prana Dwija Iswara, Tedi Supriyadi \\ Universitas Pendidikan Indonesia, Bandung, Indonesia \\ juli@upi.edu
}

\begin{abstract}
Elementary school students in Indonesia are required to learn to play traditional musical instruments, one of which is angklung (a bamboo musical instrument). However, they might have difficulty in playing angklung because angklung is a type of musical instrument that comes in an ensemble, so it must be played collaboratively. This paper aims at providing a solution for learning to play angklung easily by designing a technology-based touch angklung and implementing it in the classroom. Several computer applications and hardware were integrated to develop the touch angklung. The applications used are Sibelius, Kontakt, Sound Forge Audio Studio, and Scratch. Meanwhile, the hardware used is the MakeyMakey Kit (MMK). The development of the touch angklung comprised of sampling the angklung sounds, making angklung sound buttons on the computer, redesigning the angklung, and assembling the MMK with angklung. The touch angklung was implemented in the classroom in two schools, which consist of 30 students. Each student participated in a survey to identify the results of learning to play traditional musical instruments using the touch angklung. Observations were also carried out by the teachers and researchers. The results showed that the students had high motivation to play the touch angklung. They could play song compositions easily based on the melodies of the songs they have memorized. In conclusion, learning traditional musical instruments is more attractive to students when integrated with technology.
\end{abstract}

Keywords-Angklung learning, integrated technology, touch angklung, traditional musical instrument, elementary school

\section{Introduction}

The learning activities of traditional musical instruments in many elementary schools in Indonesia are experiencing serious problems, from the low competence of music teachers to the low interest of students to learn to play traditional musical instruments. As a result, many schools and teachers oversight the importance of learning to play traditional musical instruments, including angklung. Despite the high interest of the government and private sectors in preserving angklung through various events, such as festivals from elementary school to university level, only a small number of schools have successfully participated in such activities. The results of 
preliminary studies show that the problems that occurred in schools are the difficulty faced by the teachers in teaching and introducing angklung music to the students and the lack of enthusiasm of the students to learn to play angklung. One of the efforts that can be put to address this problem is integrating technology into the learning process in the classroom. Technology integration is the process of overcoming different barriers that hinder efficient utilization of these technologies [1]. Technology in the instruction process offers many benefits related to academic accomplishments as well as some deficiency [2].

The integration of technology in the classroom exercise is a new mode of altering instruction [3]. Changes in teaching comprise a move to problem-based learning, which not only needs students to shoulder growing concern in the learning process but also necessitates instructors to submission the kind of direction over the learning progression that they have in standard instruction. Studying is not only an occasion that occurs obviously; it is also an occasion that occurs under sure visible circumstances. According to Wilson-Strydom, et al. [4], the implementation and integration of technologies is a stimulating and multifaceted progression for schools, mainly where there is limited earlier knowledge in the use of information and communication technologies (ICTs) to provide teaching and learning. They more uphold that at numerous schools that have admitted to ICTs, the concentration has inclined to be on studying about ICTs rather than studying with or via the practice of ICTs.

This research emphasizes the incorporation of technology into learning practices. The technology integration in this research consists of combining several computer applications (i.e. Sibelius, Kontakt, Sound Forge Audio Studio, and Scratch) with MMK devices, and connecting them with angklung so that the angklung can be played by touch. MMK is a new platform for creating touchable user interfaces. It allows persons to make nature-based interfaces, it is well-matched with all software, and it does not need the user to program or to assemble electronics [5].

There have been various studies on technology integration [3, 6-8]. Lin and Chang [9] focused their research on developing physical activity in children with disabilities using MMK. Lee, et al. [10] designed the tangible interface to play Scratch games using MMK. However, research on the development of traditional musical instruments with MMK integration has not been identified, especially touch angklung in Indonesia.

This research focuses on redesigning an angklung that can be played by touch, as opposed to the standard shaking technique, and implementing it in the learning process in the classroom. Presumably, the touch technique can make elementary school students more interested and make it easier for them to play angklung because the angklung can then be played individually. Thus, it is expected that learning traditional musical instruments can be more interesting for elementary school students. 


\section{$2 \quad$ Material and Method}

\subsection{Technology for angklung}

To provide interesting learning activities for elementary school students, the standard angklung can be modified to become a technology-based touch angklung using certain software and hardware. For this research, the software used to make the touch angklung includes several computer applications, i.e. Sibelius (music notation software), Kontakt (VST plugin), Sound Forge Audio Studio (audio editing software), and Scratch (animation application). Meanwhile, the hardware used includes bamboo for angklung rods, computers for running Scratch, MMK as a controller replacement media, bolts for touch points on angklung, single cables that connect the MMK to the bolts, and loudspeakers to sound the angklung from the computer. The arrangement of the angklung, MMK, computer, and loudspeaker, can be seen in Figure 1.

\subsection{Research procedure}

There were two main stages in this research. The first stage was the redesigning process and the second stage was the implementation of touch angklung in the learning process in the classroom.

Redesigning stage: There are eight stages for making touch angklung design. They are as follows.

- Changing and redesigning the form of angklung into a simpler and cheaper musical instrument.

- Making samples of high-quality angklung sounds. The sampling of angklung sound was done through a Virtual Studio Technology (VST) plugin called Kontakt. This application was integrated into the music notation software application called Sibelius. Through Sibelius, the angklung sound was taken and stored on the computer hard drive.

- Editing the samples of angklung sounds. Each of the angklung tones was edited using the Sound Forge Audio Studio application so that the length of the sound was the same and the volume was equal.

- Making buttons and tone sequences on the computer. Every sample of the edited angklung sound needs to be played through an application that can be connected to a musical instrument. Scratch was used here to make the computer as an angklung sound controller.

- Assembling the MMK device so that the storage and installation of cables were easy.

- Connecting Scratch on the computer with the MMK device.

- Connecting the cables from MMK with angklung. Each cable represents an angklung sound.

- Connecting the computer to the speaker so that the sound of the angklung can be projected louder. 


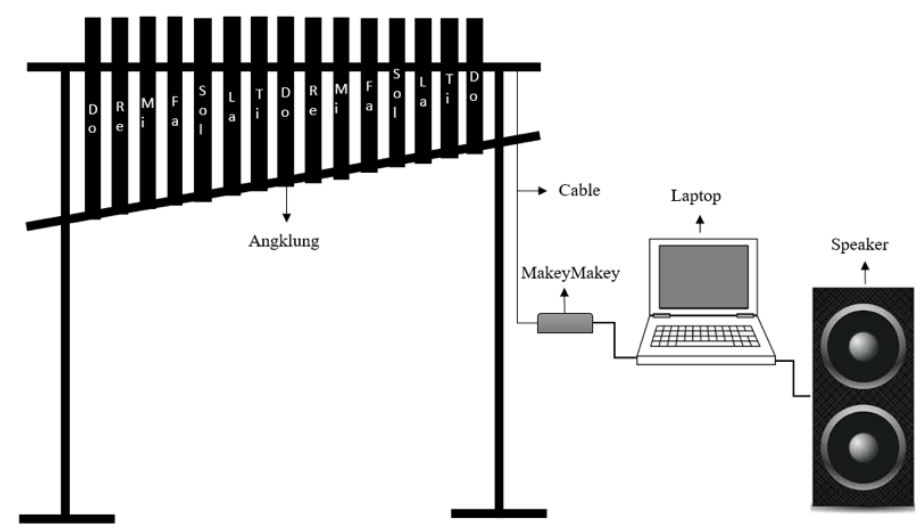

Fig. 1. Touch angklung arrangement

Implementation stage: The angklung that has been connected to the electronic devices and has sound well are then implemented in the practice of playing musical compositions in the classroom. The angklung was tested in two elementary schools. The students who participated in this practice include 10 students from school A and 20 students from school B with 14 male students and 16 female students in total. Each student played a song using the melody of the song they have memorized beforehand.

All of the students were observed while playing the angklung. They also participated in a survey after playing the angklung. At the end of the lesson, interviews were conducted with them to explore their impressions in playing angklung. The data collected through observations, surveys, and interviews are used to identify the effectiveness of touch angklung in music learning.

\section{Results and Discussion}

\subsection{Touch angklung design}

Different forms of angklung were made to be integrated with electronic devices. A standard angklung that is directly electrified required a high cost, which can be problematic at school. Alternatively, plastic materials with a round shape could not represent the identity of angklung itself. Therefore, the touch angklung was made by simplifying the materials used in standard angklung. For instance, by only using one bamboo rod directly hung on the angklung pole. With this form of angklung, the identity of angklung persists.

After several attempts to redesign the shape of the angklung, a simpler angklung design derived from the standard angklung form was achieved. The simplification includes only using one bamboo rod for the angklung touch as opposed to using two to three bamboo rods and a border like the standard angklung. This simpler design can reduce the cost of making angklung, which is usually quite expensive. Besides that, the simpler form of angklung makes it easier to play them. There were 18 angklung 
rods made for the basic melodies of songs in elementary school. Figure 2 depicts the difference between a standard angklung and a touch angklung.

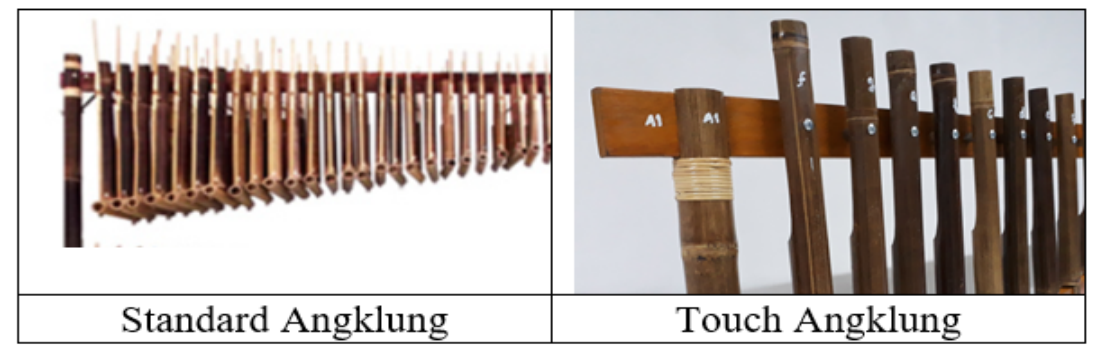

Fig. 2. Difference between standard angklung and touch angklung

To accommodate the change in the technique of playing angklung from shaking to touching, an iron was installed as a button or a point that must be touched (touch point), which simultaneously functions as an electric conductor. Stainless steel bolts were used as touch points as well as angklung hangers. The bolts were connected to MMK using a single cable on the back of the angklung. The cable was installed in each angklung tube. Figure 3 shows the cable and bolt circuit mounted on the angklung.

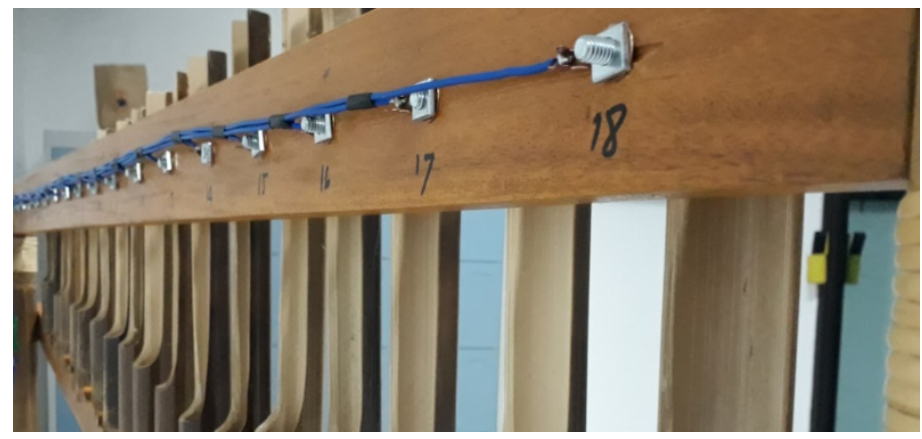

Fig. 3. Cable and bolt circuit mounted on angklung

Afterward, the neatly installed cables were connected to the MMK device. Each MMK could only produce 10 tones, so a minimum of two MMKs were needed for a series of 18 angklung tones. A hole at the bottom must be used as the ground and be worn by the player using a cable. An MMK storage or stand was made so it would not be easily damaged, and MMK cable plugs were made so that it can be easily connected to the cables that come from the angklung. The cable plugs were located at the top of the MMK storage. Thus, the cables from the touch angklung were connected to the box. The MMK storage was made of thick plastic boxes. Each box can accommodate three MMKs so that one box can be used for two sets of touch angklung. Figure 4 shows the difference between MMK without boxes and MMK after being stored in a box. 


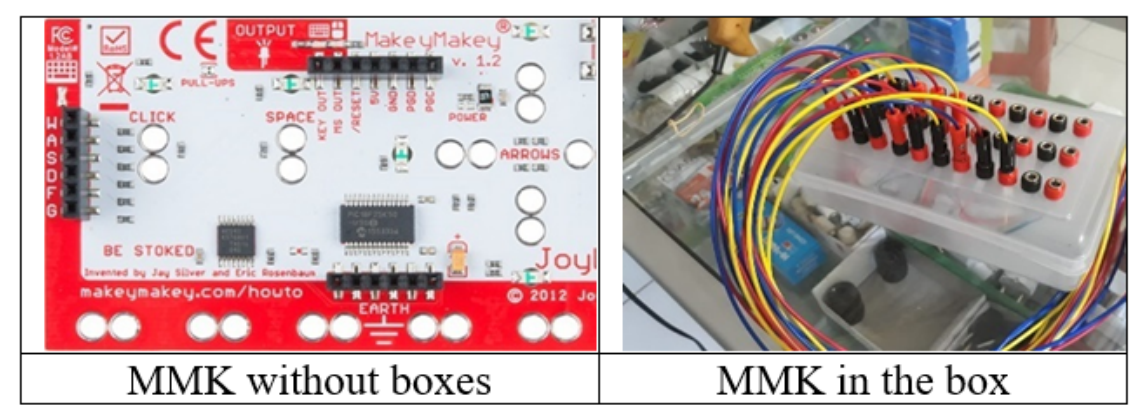

Fig. 4. MMK before and after being stored in a box

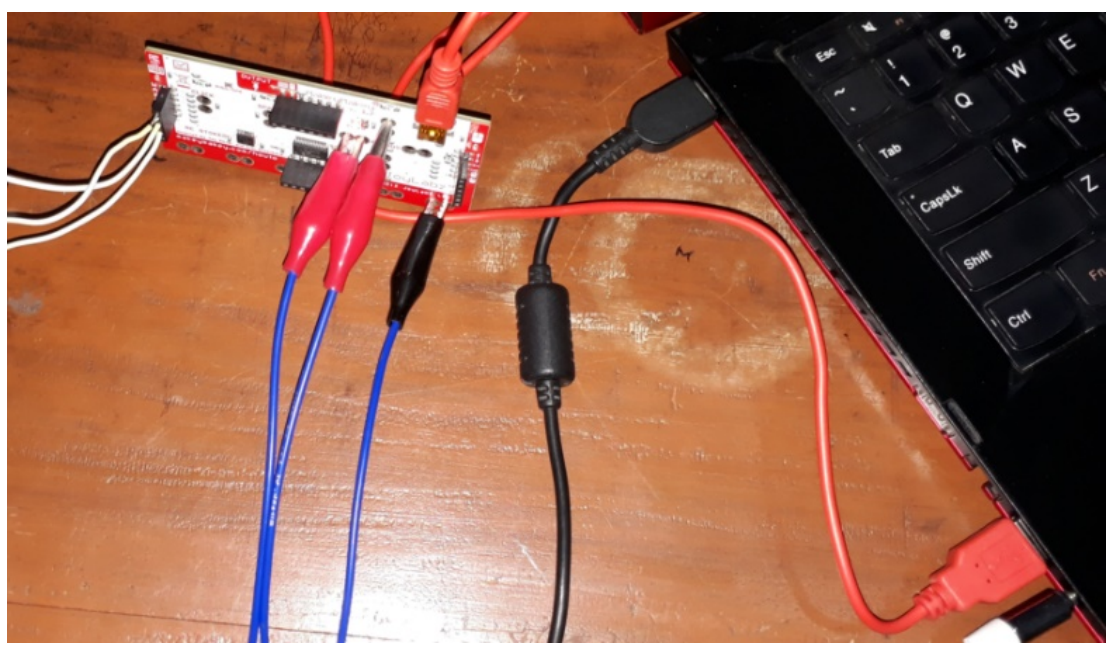

Fig. 5. MMK is connected to a laptop via a USB cable

MMK is a unique product that can be directly used instead of a game controller or music instrument controller $[11,12]$. MMK is connected to a computer using a USB cable (as shown in Figure 5). The advantages of MMK are that it can replace the keyboard function after being connected to the computer and it can be integrated with various applications. One MMK can only be used on one computer. Therefore, to use 18 angklung tones, two computers were used. Scratch was used to sequence the notes for the angklung and the settings of the buttons on the keyboard. In Scratch, various features are available to create and move images that can also be filled with sound [13]. The menus provided to command and process images and sounds are also userfriendly. Sound buttons with round images were made from $F$ to $G^{\prime}$ (10 tones). The remaining eight tones were installed on the second computer. 


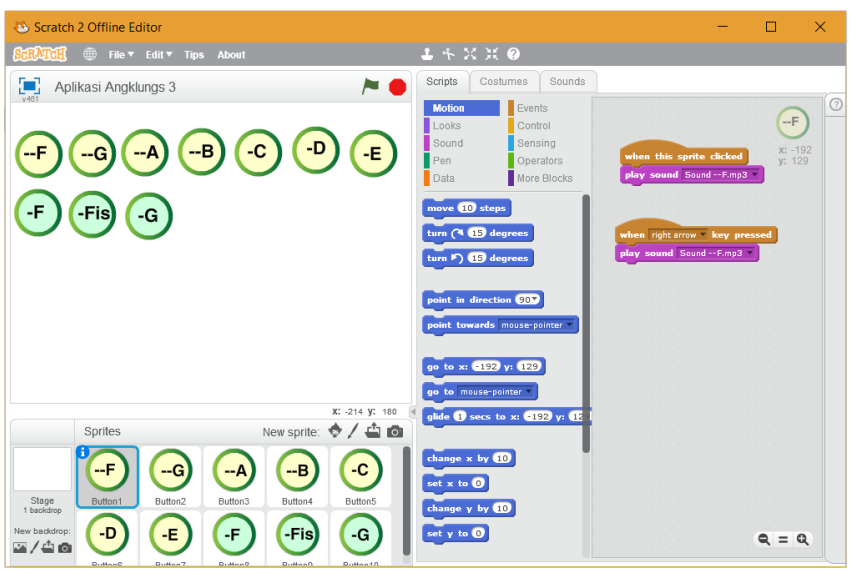

Fig. 6. Tone sequence setting on Scratch

The sound of angklung was inputted to Scratch via the Sounds menu. It can be done by recording directly or retrieving from an existing file on the hard drive. The sound of the original angklung was made into angklung sound samples in Wave format. To make angklung sound samples with good sound quality, Kontakt (as shown in Figure 7) was used as the VST plugin with Sibelius as the host. Kontakt runs as a plug-in within any audio program supporting the VST 2.0, etc. [14]. This technique can also be done to make sound samples for angklung teaching materials [15]. In this way, the type of sound in Sibelius using the MIDI type was replaced by the Kontakt sound, which used the original sound of the angklung recorded. In this research, the angklung tones were made in sequence (do-re-mi-fa-sol-la-ti-do) with Sibelius that had been integrated with Kontakt. The length of the tone made in Sibelius determined the length of the angklung sample sound. These tones were exported into Wave format and separated using Sound Forge Audio Studio (as shown in Figure 8). The tones that have been separated and edited into a touch angklung sound sample were then inputted to Scratch. The tones were sorted in Scratch based on the tone sequence in the angklung.

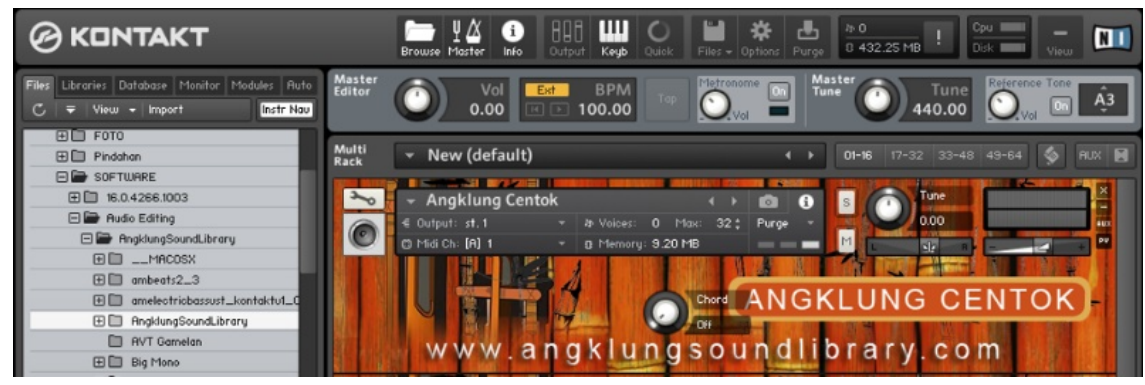

Fig. 7. Kontakt application to make angklung sound samples 


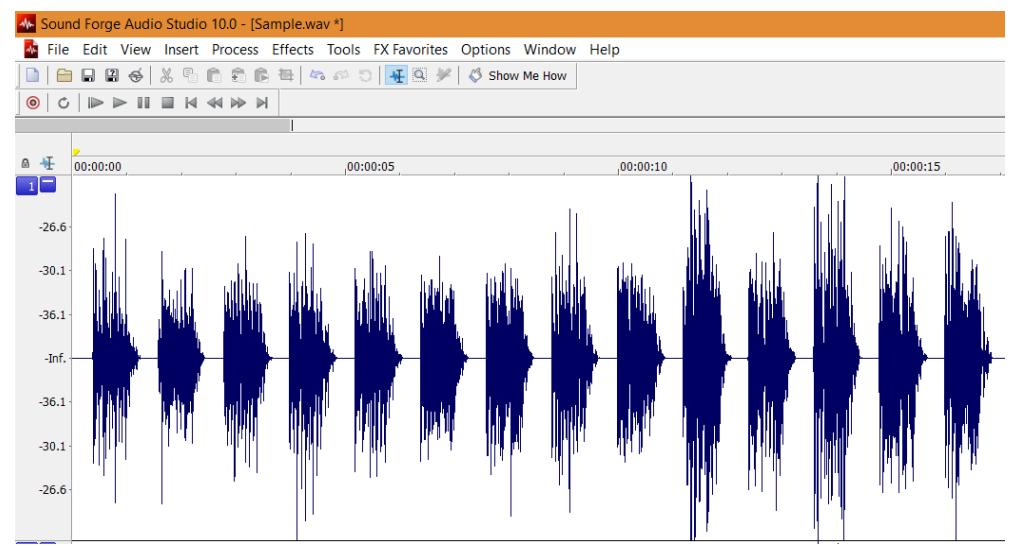

Fig. 8. Editing sound samples on Sound Forge Audio Studio

The last step in designing touch angklung is to pair the speakers on a computer. For this research, loudspeakers with a type of ALS PRO KB 50 Amplifier were used. This type of loudspeaker emits a power of 50 Watt RMS, so it is enough to amplify the sound of angklung in the classroom. With the installation of loudspeakers as the last stage, the touch angklung is ready to use. It is important to note that all the devices are connected, as in angklung-MMK-computer-speaker, so that when touched at the touch point, the angklung can sound according to the original angklung sound with shaking technique.

\subsection{Classroom implementation}

The practice of playing angklung was conducted in two music classes in two elementary schools. Each student played the melodies of familiar songs using angklung. The learning process started from playing the angklung set individually to playing it in groups. In other words, students collaborated to play one song together. All of the students were observed during the learning process. From the observation, it was identified that the students were interested to play song melodies using touch angklung. The majority of the students have mastered various song melodies well, but there were also some students who have not mastered them well. Their motivation was seen when the students who have not mastered the song melodies immediately opened the song book to memorize the melodies because they wanted to play the song using the touch angklung. The learning activities of touch angklung can be seen in Figure 9 below. 


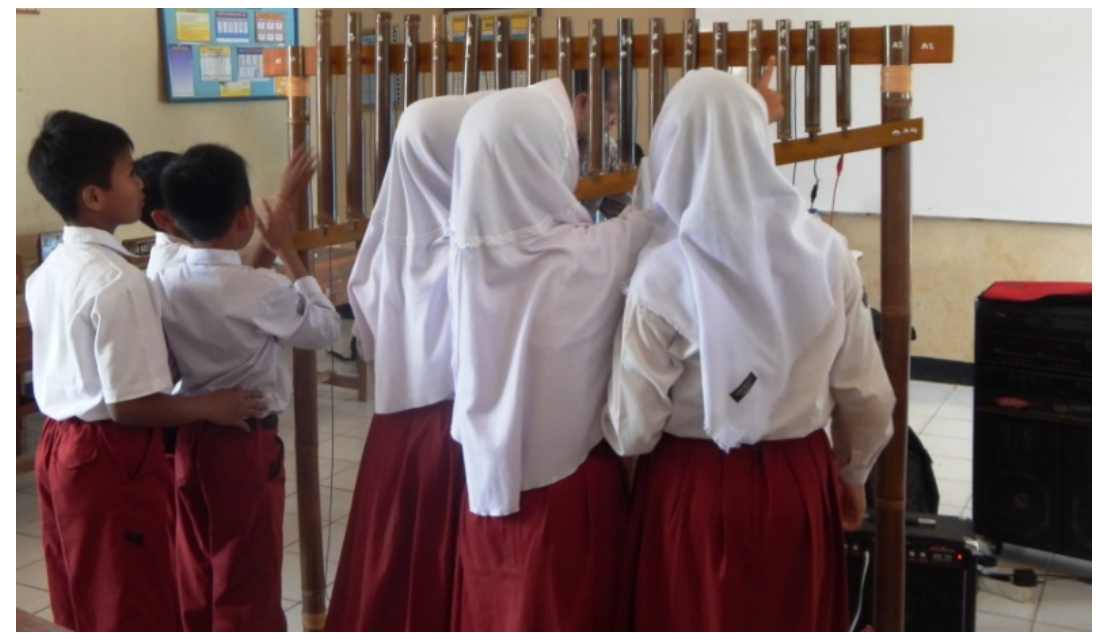

Fig. 9. Touch angklung learning activities

The complexity of playing touch angklung was evaluated. Of the 30 students who participated in the survey, the following results were obtained.

Table 1. The complexity of playing touch angklung

\begin{tabular}{|l|c|c|c|c|}
\hline \multirow{2}{*}{ Complexity } & \multicolumn{2}{c|}{ School A } & \multicolumn{2}{c|}{ School B } \\
\cline { 2 - 5 } & Yes & No & Yes & No \\
\hline Does the height of the angklung make it difficult to play angklung? & & 10 & & 20 \\
\hline $\begin{array}{l}\text { Does the distance between angklung rods make it difficult to play } \\
\text { angklung? }\end{array}$ & 4 & 6 & & 20 \\
\hline $\begin{array}{l}\text { Does the arrangement of the angklung and electronic devices disturb } \\
\text { you in playing angklung? }\end{array}$ & 3 & 7 & & 20 \\
\hline $\begin{array}{l}\text { Does the tone lengths of the angklung sound sufficient to play song } \\
\text { melodies? }\end{array}$ & 10 & & 20 & \\
\hline $\begin{array}{l}\text { Does playing the tones by touching the angklung makes it difficult to } \\
\text { play the song melodies? }\end{array}$ & 1 & 9 & & 20 \\
\hline
\end{tabular}

Note: $n=30$

Table 1 shows that all of the students $(n=30,100 \%)$ claimed to have no difficulty in playing the touch angklung in terms of the angklung's height and the tone lengths needed. However, a small number of students $(n=4,13.33 \%)$ claimed that the distance between the angklung rods caused difficulties in playing angklung, a few other $(n=3,10 \%)$ claimed that the electronic devices disturbed them when playing the angklung, and a student $(n=1,3.33 \%)$ claimed that playing angklung by touching it caused difficulties in playing the song melodies. In other words, the majority of the students (more than $80 \%$ ) have recognized that touch angklung did not cause difficulties when being played. Therefore, it can be concluded that touch angklung is not too difficult to play.

Furthermore, according to the observation, the students who have difficulties in playing the touch angklung were those who basically have not memorized the song 
melodies, so they faltered when playing a series of song melodies on the angklung. Thus, memorizing the melodies of the song is one of the keys to being able to play the touch angklung well and smoothly. Fundamentally, this applies to all musical instruments; memorizing the composition of music is an important aspect of mastering musical instruments $[16,17]$. The solution to a problem like this is to be solved by regular practice, because practice is the key to one's success, especially to hone musical competence [18-20].

In addition to the observation, a survey was conducted to identify the students' motivation in playing touch angklung. The survey results can be seen in Table 2 below.

Table 2. The motivation of students to play touch angklung

\begin{tabular}{|c|c|c|c|c|}
\hline \multirow[t]{2}{*}{ Motivation } & \multicolumn{2}{|c|}{ School A } & \multicolumn{2}{|c|}{ School B } \\
\hline & Yes & No & Yes & No \\
\hline Are you interested in playing touch angklung? & 10 & & 19 & 1 \\
\hline Do you like to play touch angklung? & 10 & & 20 & \\
\hline Is it easy for you to play the touch angklung? & 8 & 2 & 20 & \\
\hline Can you play the song melodies fast? & 4 & 6 & 17 & 3 \\
\hline Do you play the song melodies correctly? & 2 & 8 & 16 & 4 \\
\hline
\end{tabular}

Note: $n=30$

Based on Table 2, it can be identified that all of the students ( $n=30,100 \%)$ claimed to be happy to play the touch angklung. Most students $(n=29,96.67 \%)$ claimed to be interested in playing the touch angklung. Most students $(n=28$, $93.33 \%$ ) also claimed to find it easy to play the touch angklung. Meanwhile, there were some students $(n=9,30 \%)$ who claimed that they could not play fast in playing the song melodies and there were also a number of students $(n=12,40 \%)$ who claimed not to play the song melody correctly. Thus, it can be concluded that the majority of the students (more than 90\%) have recognized that they had high motivation to play touch angklung. This proves that technology has supply a positive role in elevating classroom teaching forms and increasing teaching effectiveness [21, 22]. Furthermore, the students were asked, "Why are you interested in playing touch angklung?" One of the students said, "because it is easy to play, just touch it." As for a small number of students, it was difficult to play the song melodies fast and correctly. According to the observation, the problem occurred because they have not memorized the melody of the songs and have not memorized the sequence or tonal structure of the touch angklung. Thus, memorization of song melodies is an important aspect to play the music composition well [23-26].

\section{Conclusion}

In teaching traditional musical instruments in this technological era, it is necessary to use the right strategy. Involving technology in the learning process of traditional musical instruments is a strategy that is deemed appropriate. This applies to angklung learning as well. The angklung can be redesigned in such a way to involve technology without removing the original sound of angklung. In addition, elementary school 
students are proved to be motivated to learn to play traditional musical instruments integrated with technology. Furthermore, it allows the students to play musical compositions more easily. The results of the development of angklung in this research need to be followed up by other studies to improve the new angklung design. The principle of technology used in this research can also be used for other traditional musical instruments.

\section{Acknowledgement}

Utmost gratitude is etended to the Institute for Research and Community Service (LPPM, Lembaga Penelitian dan Pengabdian kepada Masyarakat) Universitas Pendidikan Indonesia that has facilitated this research. In addition, thanks to the Indonesian Ministry of Research, Technology and Higher Education for funding this research.

\section{References}

[1] P. A. Ertmer, "Addressing first-and second-order barriers to change: Strategies for technology integration," Educational technology research and development, vol. 47, no. 4, pp. 47-61, 1999. https://doi.org/10.1007/bf02299597

[2] I. Shubina and A. Kulakli, "Pervasive Learning and Technology Usage for Creativity Development in Education," International Journal of Emerging Technologies in Learning (iJET), vol. 14, no. 01, pp. 95-109, 2019. https://doi.org/10.3991/ijet.v14i01.9067

[3] M. Z. Ramorola, "Challenge of effective technology integration into teaching and learning," Africa Education Review, vol. 10, no. 4, pp. 654-670, 2013. https://doi.org/10.1 $\underline{080 / 18146627.2013 .853559}$

[4] M. Wilson-Strydom, J. Thomson, and C. Hodgkinson-Williams, "Understanding ICT integration in South African classrooms: research: information and communication technologies," Perspectives in education, vol. 23, no. 1, pp. 71-85, 2005.

[5] B. s. M. Collective and D. Shaw, "Makey Makey: improvising tangible and nature-based user interfaces," in Proceedings of the sixth international conference on tangible, embedded and embodied interaction, 2012, pp. 367-370: ACM. https://doi.org/10.1 $\underline{145 / 2148131.2148219}$

[6] T. H. Laine and E. Nygren, "Active and passive technology integration: a novel approach for managing technology's influence on learning experiences in context-aware learning spaces," Technology, Pedagogy and Education, vol. 25, no. 1, pp. 19-37, 2016. https://doi.org/10.1080/1475939x.2014.945475

[7] X. Jia, J. Jung, and A. Ottenbreit-Leftwich, "Learning Technology Integration From a Service-Learning Project: Connecting Preservice Teachers to Real-World Problems," Journal of Experiential Education, p. 1053825917738269, 2017. https://doi.org/10.11 $\underline{77 / 1053825917738269}$

[8] L. Cifuentes, G. Maxwell, and S. Bulu, "Technology integration through professional learning community," Journal of Educational Computing Research, vol. 44, no. 1, pp. 5982, 2011. https://doi.org/10.2190/ec.44.1.d

[9] C.-Y. Lin and Y.-M. Chang, "Increase in physical activities in kindergarten children with cerebral palsy by employing MaKey-MaKey-based task systems," Research in develop- 
mental disabilities, vol. 35, no. 9, pp. 1963-1969, 2014. https://doi.org/10.1016/j.ridd.2014.04.028

[10] E. Lee, Y. B. Kafai, V. Vasudevan, and R. L. Davis, "Playing in the arcade: Designing tangible interfaces with MaKey MaKey for Scratch games," in Playful User Interfaces: Springer, 2014, pp. 277-292. https://doi.org/10.1007/978-981-4560-96-2 13

[11] J. Tanenbaum, K. Tanenbaum, K. Isbister, K. Abe, A. Sullivan, and L. Anzivino, "Costumes and wearables as game controllers," in Proceedings of the Ninth International Conference on Tangible, Embedded, and Embodied Interaction, 2015, pp. 477-480: ACM. https://doi.org/10.1145/2677199.2683584

[12] J. Tanenbaum and K. Tanenbaum, "Envisioning the Future of Wearable Play: Conceptual Models for Props and Costumes as Game Controllers," in FDG, 2015.

[13] M. Resnick et al., "Scratch: programming for all," Communications of the ACM, vol. 52, no. 11 , pp. 60-67, 2009.

[14] S. Chameleon, "Products of Interest," Computer Music Journal, vol. 26, no. 4, pp. 113$121,2002$.

[15] J. Julia, T. Supriyadi, and P. D. Iswara, "The development of angklung composition teaching materials using music notation software with virtual studio technology integration," presented at the International Conference on Mathematics and Science Education (ICMScE), Bandung, Indonesia, In Press. https://doi.org/10.1088/1742-6596/1157/4/042005

[16] J. Ginsborg, R. Chaffin, and G. Nicholson, "Shared performance cues in singing and conducting: A content analysis of talk during practice," Psychology of Music, vol. 34, no. 2, pp. 167-194, 2006. https://doi.org/10.1177/0305735606061851

[17] G. Rubin-Rabson, "Studies in the psychology of memorizing piano music. VI: A comparison of two forms of mental rehearsal and keyboard overlearning," Journal of Educational Psychology, vol. 32, no. 8, p. 593, 1941. https://doi.org/10.1037/h0058481

[18] F. Rauscher, G. Shaw, L. Levine, E. Wright, W. Dennis, and R. Newcomb, "Music training causes long-term enhancement of preschool children's spatial-temporal reasoning," Neurological research, vol. 19, no. 1, pp. 2-8, 1997. https://doi.org/10.1080/0 1616412.1997.11740765

[19] N. Kraus and B. Chandrasekaran, "Music training for the development of auditory skills," Nature reviews neuroscience, vol. 11, no. 8, p. 599, 2010. https://doi.org/10.1038/nrn2882

[20] A. S. Chan, Y.-C. Ho, and M.-C. Cheung, "Music training improves verbal memory," Nature, vol. 396, no. 6707, p. 128, 1998. https://doi.org/10.1038/24075

[21] Y. Gong, "Innovative English Classroom Teaching Based on Online Computer Technology in Rural Middle and Primary Schools," International Journal of Emerging Technologies in Learning (iJET), vol. 13, no. 10, pp. 4-14, 2018. https://doi.org/10.3 991/ijet.v13i10.9449

[22] Z. Guo and L. Xu, "Study on the integration mode of computer network technology and college English curriculum," International Journal of Emerging Technologies in Learning (iJET), vol. 11, no. 08, pp. 40-46, 2016. https://doi.org/10.3991/ijet.v11i08.6046

[23] C. Palmer, "The nature of memory for music performance skills," Music, motor control and the brain, pp. 39-53, 2006. https://doi.org/10.10 93/acprof:oso/9780199298723.003.0003

[24] A. Williamon and E. Valentine, "The role of retrieval structures in memorizing music," Cognitive psychology, vol. 44, no. 1, pp. 1-32, 2002. https://doi.org/10.1 006/cogp.2001.0759

[25] S. Lim and L. G. Lippman, "Mental practice and memorization of piano music," The Journal of General Psychology, vol. 118, no. 1, pp. 21-30, 1991. https://doi.org/10.10 $\underline{80 / 00221309.1991 .9711130}$ 
Paper-Redesigning and Implementing Traditional Musical Instrument in Integrated Technology...

[26] R. A. Duke and C. M. Davis, "Procedural memory consolidation in the performance of brief keyboard sequences," Journal of Research in Music Education, vol. 54, no. 2, pp. 111-124, 2006. https://doi.org/10.1177/002242940605400203

\section{$7 \quad$ Authors}

J. Julia is a senior lecturer at the Elementary School Teacher Education Study Program, Faculty of Education, Universitas Pendidikan Indonesian, Jl. Dr. Setiabudhi No. 229, Bandung, Jawa Barat, Indonesia. He lectures on Music Education, Technology for Music, and Traditional Musical Instruments.

Prana Dwija Iswara is a senior lecturer at the Elementary School Teacher Education Study Program, Faculty of Education, Universitas Pendidikan Indonesian, Jl. Dr. Setiabudhi No. 229, Bandung, Jawa Barat, Indonesia.

Tedi Supriyadi is a lecturer at the Elementary School Teacher Education Study Program, Faculty of Education, Universitas Pendidikan Indonesian, Jl. Dr. Setiabudhi No. 229, Bandung, Jawa Barat, Indonesia.

Article submitted 2019-01-22. Resubmitted 2019-03-04. Final acceptance 2019-03-06. Final version published as submitted by the authors. 